\title{
Identifying enablers of innovation in developed economies: A National Innovation Systems approach
}

\author{
Agostino Menna \\ agostino@knowquest.net | KnowQuest Inc. 3754 Rolling Acres Drive Niagara Falls, Ontario, Canada, \\ L2J 3B9 \\ Philip R. Walsh \\ prwalsh@ryerson.ca | Ted Rogers School of Management, Department of Entrepreneurship \& Strategy, \\ Ryerson University \\ Homeira Ekhtari \\ hekhtari@ryerson.ca| Ted Rogers School of Management, Information Technology Management, \\ Ryerson University
}

\begin{abstract}
It has been recognized that innovation drives the long-run economic growth of nations and increasingly governments are placing innovation at the center of their economic growth strategies. International variation in the investment on innovation presents an opportunity to examine key enablers of innovation-driving policy choices. Countries find themselves at different stages of economic development and innovation performance and so their relative levels of innovation inputs and outputs are likely to be different. In this study we employ a systems of innovation approach to examine what enables improvements in innovation potential among developed countries. Using data from the 2017 Global Innovation Index (GII) Report, we subjected 770 data measures to an analysis of 242 relationships involving changes in the GII's innovation inputs/outputs scores and overall innovation potential of 35 OECD countries over a five year period (2012 to 2016). Our findings suggest that instituting policies that improve access to open and competitive markets is the most significant enabler for raising a developed country's innovation potential.
\end{abstract}

Keywords. Innovation Enablers, Innovation Policy, OECD, Developed Economies, National Innovation Systems.

Cite paper as: Menna, A., Walsh, P., Ekhtari, H., (2019). Identifying enablers of innovation in developed economies: A National Innovation Systems approach, Journal of Innovation Management, www.open-jim.org, 7(1), 108128. HANDLE: https://hdl.handle.net/10216/119830; DOI: https://doi.org/10.24840/2183-0606_007.001_0007 


\section{Introduction}

Countries increasingly recognize that innovation drives long-run economic growth and governments are putting innovation at the center of their growth strategies (INSEAD, 2017). Investment in innovation is an important contributor to productivity and the growth of an economy (Hassan and Tucci, 2009; Roberts, 1998; Chen, 2009; Chol, 1990). The extant literature on innovation's role on economic growth is voluminous (Mansfield, 1980; Romer, 1986; Griliches and Mairesse, 1986; Stokey, 1995; Fagerberg, 1994; Kirchoff, 1994; Wennekers, 1999; Audretsch, 1995; Abiad et. al., 1989). Growing attention to the Schumpterian theory of economic growth has drawn attention to the role that technological change and innovation play in achieving economic growth (Watkins et. al., 2015). This has attracted considerable research interest in the enablers of the innovation process itself (Crespo and Crespo, 2016; Furman, Porter and Stern, 2002; Lui and Buck, 2007; Grossman and Helpman, 1991). International variation in the investment on innovation presents an opportunity to examine key enablers of innovation-driving policy choices. Countries find themselves at different stages of economic development and innovation performance and so their relative levels of innovation inputs and outputs are likely to be different (Vivarelli, 2014; Watkins et. al., 2015; Crespo and Crespo, 2016). For innovation policy makers in developed countries the driver for improving their innovation potential is premised on the realization that while innovation (particularly that of a process orientation) can reduce employment, improving a country's potential to innovate will result in increased investment in capital goods, lower prices to drive consumption, new products and higher average wages (Vivarelli, 2014). A comprehensive review of the general literature dealing with innovation enablement was undertaken to determine a suitable conceptual framework and provide empirical support for the relationship within inputs and outputs of innovation (predicator variables) and with the Global Innovation Index (GII), (criterion variable). An analysis of the rankings of indices helps policymakers and governments, particularly in industrialized countries, to identify paths for future development and design innovation policies (Balzat and Hanusch, 2004; Mahroum and Al-Saleh, 2013). The principal research question driving this study is: What enables improvements in innovation potential among developed countries?

In total, 770 data measures were subjected to an analysis of 242 relationships involving changes in the GII's innovation inputs/outputs scores and overall innovation potential of 35 OECD countries over a five year period (2012 to 2016). This study adopted an indicators method of national innovation performance and considered the following characteristics (Grupp and Schubert, 2010): the indicators are of comparable importance as measures of the concept under study, the indicators are based on reliable statistics; the indicators hold their value over time; and the indicators are relevant to medium and long-term policy issues (Carayannis and Grigoroudis, 2014). To understand the key determinants that drive innovation, this study used Pearson correlation coefficients and stepwise linear regression modeling to observe the relationships among these determinants that might inform innovation policy-makers. This follows a "systems of innovation approach" (NIS) in terms of enablers of, or factors influencing, innovation. This approach includes economic, social, political organizational, institutional and other factors that influence the diffusion and use of innovation (Edquist, 1997b; Nelson, 1993, Lundvall, 1992).

We have organized our article by starting with a general discussion regarding innovation com- 
petitiveness and globalization. This is followed by some background regarding the concept of national innovation systems and then a description of what is involved in the GII framework. The next section describes the methodology we employed in our study followed by our results and discussion. We conclude with a discussion of the implications of our findings and identify some of the limitations of our study.

\section{Innovation Competitiveness}

Technology entrepreneurs often compete in dynamic and fierce environments (D'Aeni, 1994) and need to develop and commercialize new products in order to exploit promising market opportunities, generate cash flows and make a profit (Haeussler et. al., 2012). A knowledge-based global economy emphasizes the need of a country to develop its innovative potential, given that the competitive performance of a national economy depends on the formation of intellectual capital and the society's capacity to innovate (Carayannis and Grigoroudis 2014). Yet, developing, testing and commercializing innovations can be a costly and time consuming process and financial outcomes risky. In order to decrease the risks of innovation and achieve the benefits of innovativeness, it is important to understand the key enablers. One of the most important stimuli of innovativeness is public policy support (Wojnicka-Syez and Syez, 2016). The role of public policy in Schumpeterian economics generally reflects the importance of entrepreneurial start-ups in generating innovation, economic growth and competitiveness in globally linked markets (Ferreira et. al., 2017; Audretsch et. al., 2012). Researchers have sought to explain the determinants of innovation, from a micro perspective, by identifying a number of critical success factors of innovation such as the firm's size (Fritsch and Meschede, 2001), strategy and social capital (Balachandra and Friar, 1997). Other research has shown innovation determinates from a macro perspective, mainly from the research and development (R\&D) function, patents and governance (Fagerberg and Srholec, 2008; Becheikh at al., 2006a). According to an OECD survey on a sample of 20 OCED countries over the period 1982-2001, the main determinants of countries innovativeness appear to be the availability of scientist and engineers, research conducted in the public sector, business-academic links, the degree of product-market competition and the a high level of financial development and access to foreign inventions (OECD, 2005: 33).

The link between R\&D and other macro functions is of great interest to governments (MacPherson, 1997). Governments formulate policies and offer services destined to promote and support technological innovation, with the hope that it will translate into higher levels of innovation, growth and internationalization of firms (Raymond and St. Pierre, 2010; Ouellet and Raoub, 2006). Ultimately this strategy leads to innovation as a competitive advantage. Porter's seminal work developed this linkage when he identifiedtwo existing models that make a country and organization competitive: the first model uses efficiency as the source of competitive advantage and is mainly operated by multinationals; the second model is based on innovation and growth to meet the individualized needs of the consumer (Porter, 1991). This environment emphasizes technological progress powered by entrepreneurship and innovation and leads to the creation of product and process innovations. Later work by the Global Entrepreneurship Monitor (2016) described this type of environment as "innovation driven" and found within advanced global economies. These economies have the ability to produce innovative products and services at the 
global technological frontier using the most advanced methods and are the dominant source of competitive advantage. At this stage, the national business environment is characterized by the presence of deep clusters. Clusters become critical motors not only in generating productivity but encouraging innovation at the world frontier. Institutions and incentives supporting innovation are also well developed, increasing the efficiency of cluster interaction. Companies compete with unique strategies that are often global in scope, and invest strongly in advanced skills, the latest technology, and innovative capacity (Delgado et. al., 2012). Therefore, innovation-driven competitiveness is critical for a country's long run economic performance (Carayannis and Grigoroudis, 2014).

\section{A Systems Approach to Innovation}

The concept of National innovation systems (NIS) have its origin in the influential work of Joseph Schumpeter. He recognized that innovation and ultimately economic growth is not autonomous, being dependent on factors outside of it. Since these factors are many, no one-factor can ever be satisfactory (Schumpeter, 1947). Schumpeter's insight was further supported by research introduced in the late 1980s (Freeman, 1987; Dosi et. al., 1988) and expounded upon in subsequent years (Lundvall, 1992; Nelson, 1993; Edquist, 1997). Furman et al., (2002) defined NIS as the ability of a country - as both a political and economic entity- to produce and commercialize a flow of new-to-the world technologies over the long term and Oglobina et al. (2002) and Godin (2007) found that such ability relies on a larger system composed of national institutional sectors and their environments. Lunval (2007) identified two schools of thought in the literature about NIS. The first, tends to define innovation in a narrow sense by focusing on science and technology policy, and mostly analyzes the systemic relationships between R\&D efforts in firms. The other school of thought looks at innovation in a broader sense and defines innovation as a continuous cumulative process involving not only radical and incremental innovation, but also the diffusion, absorption and use of innovation, beside science (Nasierowski, 2009). The framework also emphasized the relationships between the components or sectors as the "cause" explaining the performance of innovation systems (Godin, 2007). In short, a national innovation system can be perceived as a historically grown subsystem of the national economy in which various organizations and institutions interact with and influence one another in the carrying out of innovative activity (Balzat and Hanusch, 2004). The systemic approach to innovation is based on the notion of non-linear and multidisciplinary innovation processes. Interactions on the organizational level as well as the interplay between organizations and institutions are given central significance (Nelson, 1993). This in turn is consistent with the dynamics capabilities concept of strategy, that sees a firm's ability to deploy and exploit resources as critical to its competitiveness (Amit and Schoemaker,1993; Teece et. al., 1997). For firms engaged in innovation commercialization within fast-changing environments, a Schumpeterian approach to innovation is likely to be more important (Lim et al., 2013). Ultimately, the NIS approach not only contributes to innovation, but is almost totally defined in terms of, and dedicated to, innovation as commercialization of technological invention (Godin, 2006a).

Connecting the level of NIS development with the level of economic advancement along structural and institutional development is critical in order to avoid defining pathways that are impossible 
to achieve (Gu, 1999, Watkins et al. 2015). High income and low income countries demonstrate different paradigms of economic development, and as such, the dimensions that support their innovation performance should be distinct (Watkins et. al., 2015; Crespo and Crespo, 2016).

\subsection{GII Innovation Framework}

Since the late 1990s, the most collective approach to compare the performances of different innovation systems is the use of indices and rankings. The appeal of indices and rankings is based on political and operational importance for decision-making. An analysis of the rankings of these indices helps policymakers and governments throughout the world, particularly in industrialized countries, to identify paths for future development and design innovation policies (Sonorexa and Moodie, 2013). In 2007, the INSEAD Business School, Cornell University, and the World Intellectual Property Organization (WIPO) developed the GII to evaluate the level of innovative potential in national socioeconomic systems and to support the development of policies and practices that stimulate innovation. The use of this particular index as a measure of national innovation capability has been recognized in the recent innovation literature (Al-Sudairi et al., 2014; Crespo \& Crespo, 2016; Jackson et al., 2016; Sohn et al., 2016; Prim et al., 2017). The GII depends on two sub-indices, each one developed on several enablers. Over time, this index has improved, and by 2015 included 79 indicators divided into 5 input enablers (institutions, human capital and research, infrastructure, market sophistication and business sophistication and two output enablers, knowledge and technology outputs and creative outputs.

\section{Methodology}

Each of the innovation inputs and innovation outputs contained within the GII framework are measured for each country by using a number of metrics that are combined to provide their respective scores. The input/output scores are then aggregated to provide an overall innovation potential score for each country in the study. The measures included in the GII framework are described in the Appendix. For the purpose of further analysis we have created a conceptual model as shown in Figure 1. The authors (Dutta et al. 2016, pg. 49) of the GII recognize that it is not a tool that can provide "the ultimate and definitive ranking of economies with respect to innovation" but they support their framework by stating that "The rich metrics can be used - on the level of the index, the sub-indices, or the actual raw data of individual indicators - to monitor performance over time and to benchmark developments against countries in the same region or of the same income category."

With that observation in mind, and the empirical evidence within the literature that supports isolating high income from low income countries when using the GII for analysis (Crespo and Crespo, 2016), we have chosen to focus on the GII data associated with OECD member countries. Accordingly our principal research question that we seek to address is "what enables improvements in innovation potential among developed countries"?

To measure improvement or deterioration in a country's innovation potential we have chosen to 
compare the change in a country's GII score with changes in both innovation inputs and outputs over a five year period (2012-2016) relying on data published annually by Cornell University, Insead and the World Intellectual Property Organization in their Global Innovation Index report. Our sample is comprised of 35 country members of the Organisation for Economic Co-operation and Development as listed in Table 1. Given the continuous nature of the scoring data, a Pearson correlation was run to determine if there were any significant relationships between increases or decreases in a country's GII score over that five year period when compared to any increases or decreases in a country's scores for each of the innovation inputs and outputs, Upon determining statistically significant relationships, and in order to explore for any predictive variables, stepwise linear regression modelling was undertaken. Our sample of developed countries are missing only three of the total number of developed economies as identified by the United Nations; Bulgaria, Croatia and Cyprus. ${ }^{1}$

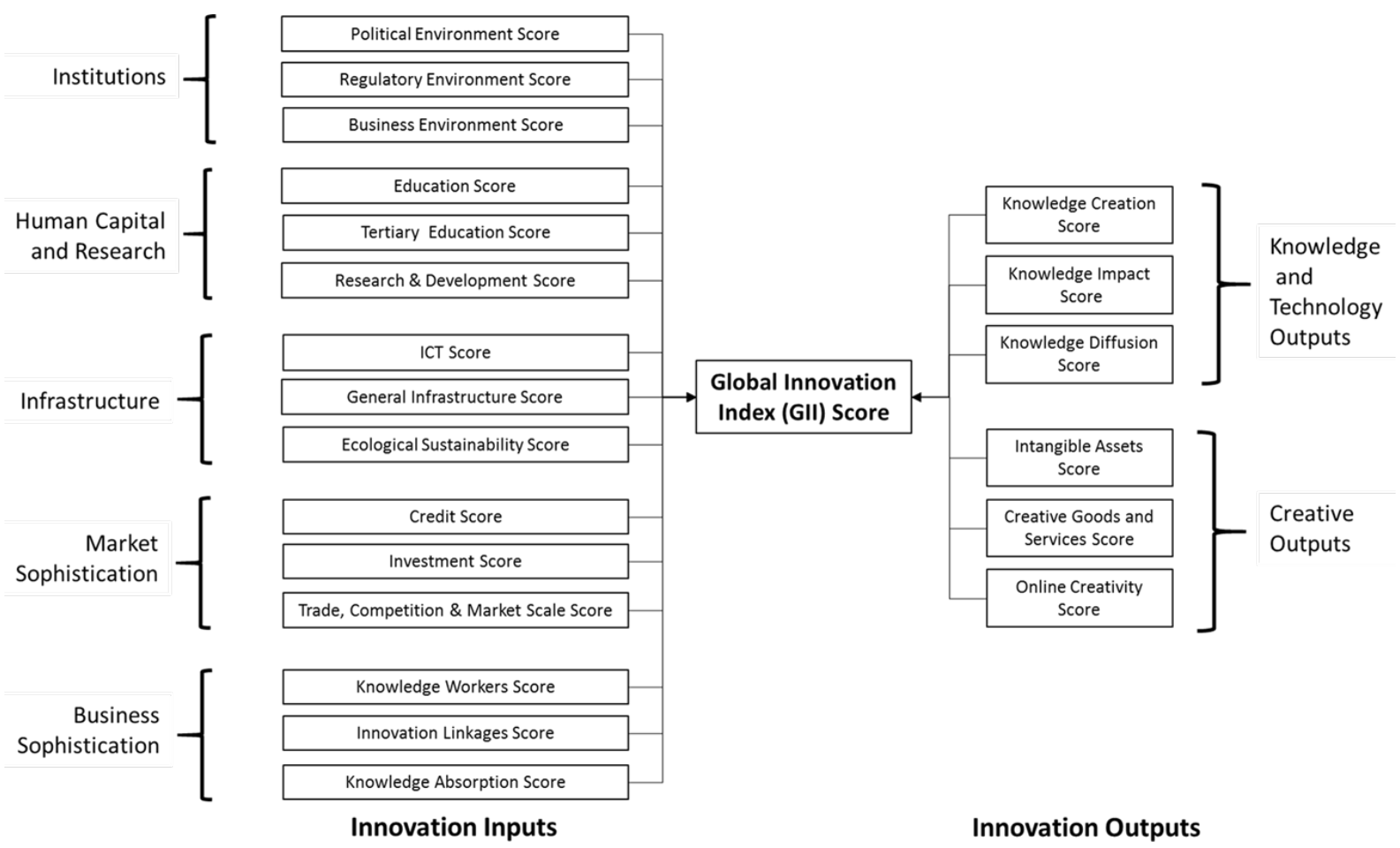

Fig. 1. Drivers of Innovation Research Model after Dutta et al. 2016

The change in GII score is the dependent variable and changes in those innovation inputs or outputs that were statistically significantly correlated to GII are the independent variables. In addition, we wish to further examine any innovation inputs or outputs that might influence the predictive variables by identifying any statistically significant correlations between them. As the GII score is determined using the respective country's innovation inputs and output scores we are watchful for any collinearities that might exist in the data. Accordingly we will test for multi-collinearity between variables by calculating the variance inflation factor (VIF) in our regressions and employ the Durbin-Watson test on any regression models.

$\overline{1}$ http://www.un.org/en/development/desa/policy/wesp/wesp_current/2014wesp_country_classification.pdf 


\section{Results and Discussion}

In total, 770 data measures were subjected to an analysis of 242 relationships. Table 2 provides the results of the Pearson correlations between the 5 year change in GII score and the corresponding changes in scores for innovation inputs. A statistically significant and strongly positive relationship $(\mathrm{R}=.515, p=.002)$ was found between a change in a country's Trade, Competition and Market Scale (Trade et al) score and the change in its GII score. This result is not surprising given that improving the market conditions for trade, encouraging competition that might stimulate innovation among market participants, and increasing the scale of the domestic market and its innovation capacity could positively impact a country's ability to advance its innovation potential. Our result also finds support in the literature. Baldwin and $\mathrm{Gu}$ (2004) in their empirical study of trade liberalization and increased export capacity in Canada found that improving access to export markets increased the innovative capacity of firms. In a literature review on the relationship of market scale and innovation, Dubois et al. (2015) found that for large industries like the pharmaceutical industry, the larger the market the greater the amount of innovation and while Stagni et al. (2017) found that increased competition can limit the type of innovation they also discovered that competition increases firm diversification and innovation exploration. A more moderate, yet statistically significant, positive relationship was found to exist between the change in a country's GII score and its knowledge absorption score.

Table 1. OECD sample countries

\begin{tabular}{lccc}
\hline Country & $\begin{array}{c}\text { Gross Domestic } \\
\text { Product (GDP) } \\
(\mathbf{2 0 1 6 )} \text { in US\$ } \\
\text { billions }\end{array}$ & $\begin{array}{c}\text { GII Income } \\
\text { Group }\end{array}$ & GII Region \\
\hline Australia & $1,256.6$ & High Income & SE Asia, East Asia, and Oceania \\
Austria & 387.3 & High Income & Europe \\
Belgium & 470.2 & High Income & Europe \\
Canada & $1,532.3$ & High Income & Northern America \\
Chile & 234.9 & High Income & Latin America and the Caribbean \\
Czech Republic & 193.5 & High Income & Europe \\
Denmark & 302.6 & High Income & Europe \\
Estonia & 23.5 & High Income & Europe \\
Finland & 239.2 & High Income & Europe \\
France & $2,488.3$ & High Income & Europe \\
Germany & $3,494.9$ & High Income & Europe \\
Greece & 195.9 & High Income & Europe \\
Hungary & 117.1 & High Income & Europe \\
Iceland & 19.4 & High Income & Europe \\
Ireland & 307.9 & High Income & Europe \\
Israel & 311.7 & High Income & Northern Africa and Western Asia \\
Italy & $1,852.5$ & High Income & Europe \\
& & &
\end{tabular}




\begin{tabular}{|c|c|c|c|}
\hline Country & $\begin{array}{c}\text { Gross Domestic } \\
\text { Product (GDP) } \\
(2016) \text { in US } \$ \\
\text { billions }^{1}\end{array}$ & $\begin{array}{l}\text { GII Income } \\
\text { Group }\end{array}$ & GII Region \\
\hline Japan & $4,730.3$ & High Income & SE Asia, East Asia, and Oceania \\
\hline Korea, Republic of & $1,404.4$ & High Income & SE Asia, East Asia, and Oceania \\
\hline Latvia & 27.9 & High Income & Europe \\
\hline Luxembourg & 61.0 & High Income & Europe \\
\hline Mexico & $1,063.6$ & $\begin{array}{l}\text { Upper- } \\
\text { Middle } \\
\text { Income }\end{array}$ & Latin America and the Caribbean \\
\hline Netherlands & 769.9 & High Income & Europe \\
\hline New Zealand & 179.4 & High Income & SE Asia, East Asia, and Oceania \\
\hline Norway & 376.3 & High Income & Europe \\
\hline Poland & 467.4 & High Income & Europe \\
\hline Portugal & 205.9 & High Income & Europe \\
\hline Slovakia & 90.3 & High Income & Europe \\
\hline Slovenia & 44.1 & High Income & Europe \\
\hline Spain & $1,252.2$ & High Income & Europe \\
\hline Sweden & 517.4 & High Income & Europe \\
\hline Switzerland & 662.5 & High Income & Europe \\
\hline Turkey & 735.7 & $\begin{array}{l}\text { Upper- } \\
\text { Middle } \\
\text { Income }\end{array}$ & Northern Africa and Western Asia \\
\hline United Kingdom & $2,649.9$ & High Income & Europe \\
\hline United States & $18,561.9$ & High Income & Northern America \\
\hline
\end{tabular}

${ }^{1}$ As reported by GII

The GII measures knowledge absorption principally through the ability of a country's high tech sector to acquire information and information technology related to innovation, to encourage inflows of foreign investment that will allow domestic firms to be exposed to global innovation, and the measure of local professionals engaged in acquiring intellectual property. To find in the data a positive relationship between greater knowledge absorption and a county's improved GII score is also reasonable and is consistent with the work of Forés and Camisón (2016) who found that the absorptive capacity of firms has a significant positive effect on innovation performance.

Table 3 contains the results of the Pearson correlations between the 5 year change in GII score and the corresponding changes in scores for innovation outputs. Moderate and statistically significant relationships exist between the increase in a country's overall innovation score and its ability to improve knowledge creation capabilities $(\mathrm{R}=.475, p=.004)$ and the ability to diffuse that knowledge $(\mathrm{R}=.386, p=.022)$. The latter result is interesting because the GII framework is designed so that knowledge diffusion output measures are a "mirror" of the knowledge absorption 
input measures (Dutta et al. 2016, p.55). As opposed to the ability to acquire information as a benefit for enhancing innovation, the diffusion output measures the value received (royalties and fees, technology exports, foreign direct investment) for being able to disseminate the knowledge derived from innovation activities. Given the framework design, to find similar results for both as significant contributors to a country's overall innovation potential is therefore not unsurprising. Furthermore, these results are consistent with the description by Zanello et al. (2016) that the innovation process is one where investments are made in knowledge building activities that support the creation, diffusion and absorption of innovation. Finally, a moderate relationship exists between that the intangible assets associated specifically with creative outputs and the overall growth in a nation's innovation standing $(\mathrm{R}=.486, p=.004)$. The output measures include national trademark and design applications as well as the use of ICT within the businesses and organizations of the country. The literature continues to support these measures as contributors to improving regional or national innovation potential and support our findings here (Billon et al. 2017; Khedhaouria and Thurik, 2017).

Having identified some significant relationships between improvements in specific inputs and outputs and overall improvement of a country's innovation standing we now focus on their predictive capabilities. Stepwise regression was employed to determine the relative predictive contribution of each

Table 2. Correlations - Change in Innovation Inputs Score with Change in Global Innovation Index Score $(\mathrm{n}=35)$

Human Capital and Research

\begin{tabular}{lccc}
\hline & Education & Tertiary Education & Research and Development \\
\hline $\begin{array}{l}\text { Pearson } \\
\text { Corr. }\end{array}$ & .008 & .063 & .231 \\
\hline Sig. & .963 & & .181 \\
\hline
\end{tabular}

Infrastructure

\begin{tabular}{lccc}
\hline & $\begin{array}{c}\text { Information } \\
\text { Communication Technology } \\
\text { (ICT) }\end{array}$ & General Infrastructure & Ecological Sustainability \\
\hline $\begin{array}{l}\text { Pearson } \\
\text { Corr. }\end{array}$ & .080 & .214 & -.297 \\
\hline Sig. & .648 & .217 & .083 \\
\hline
\end{tabular}

Market Sophistication

\begin{tabular}{lccc}
\hline & Credit & Investment & $\begin{array}{c}\text { Trade, Competition \& } \\
\text { Market Scale }\end{array}$ \\
\hline $\begin{array}{l}\text { Pearson } \\
\text { Corr. }\end{array}$ & -.157 & -.135 & $.515^{* *}$ \\
\hline Sig. & .367 & .438 & .002 \\
\hline
\end{tabular}


Business Sophistication

\begin{tabular}{lccc}
\hline & Knowledge Workers & Innovation Linkages & Knowledge Absorption \\
\hline $\begin{array}{l}\text { Pearson } \\
\text { Corr. }\end{array}$ & .208 & .262 & $.410^{*}$ \\
\hline Sig. & .230 & & .014 \\
\hline
\end{tabular}

*. Correlation is significant at the 0.05 level (2-tailed).

**. Correlation is significant at the 0.01 level (2-tailed).

Table 3. Correlations - Change in Innovation Outputs Score with Change in Global Innovation Index Score $(\mathrm{N}=35)$

\begin{tabular}{lccc|ccc} 
& \multicolumn{2}{c|}{ Knowledge and Technology } & \multicolumn{3}{c}{ Creative Outputs } \\
\cline { 2 - 7 } & $\begin{array}{c}\text { Knowledge } \\
\text { Creation }\end{array}$ & $\begin{array}{c}\text { Knowledge } \\
\text { Impact }\end{array}$ & $\begin{array}{c}\text { Knowledge } \\
\text { Diffusion }\end{array}$ & $\begin{array}{c}\text { Intangible } \\
\text { Assets }\end{array}$ & $\begin{array}{c}\text { Creative } \\
\text { Goods and } \\
\text { Services }\end{array}$ & $\begin{array}{c}\text { Online } \\
\text { Creativity }\end{array}$ \\
\hline $\begin{array}{l}\text { Pearson } \\
\text { Corr. }\end{array}$ & $.475^{* *}$ & .223 & $.386^{*}$ & $.486^{* *}$ & .271 & .317 \\
\hline Sig. & .004 & .198 & .022 & .003 & .115 & .063 \\
\hline
\end{tabular}

*. Correlation is significant at the 0.05 level (2-tailed).

**. Correlation is significant at the 0.01 level (2-tailed).

to multi-variate regression models. Table 4 provides the results of the regressions with Trade et al, Knowledge Diffusion and Intangible Assets being included in the predictive models and Knowledge Absorption and Knowledge Creation being excluded. Model 3 combined all three predictive variables improving the total correlation co-efficient or strength of association $(\mathrm{R}=.714)$ and resulting in a relatively high explanation of variance $\left(\mathrm{R}^{2}=.549\right)$. The validity of Model 3 was examined by firstly adjusting the $\mathrm{R}^{2}$ for the number of independent variables included in the model. The result indicating that the model continues to explain or predict over half of the variability of the increase in the GII score (Adjusted $\mathrm{R}^{2}=.505$ ). A Durbin-Watson test was conducted to identify if any autocorrelation or non-independence exists within the variables and the test outcome approaches 2 (1.984) confirming the independence of the data. Finally, multicollinearity within the data was analyzed to determine if the variance of the co-efficient estimate was being influenced by any collinearity between the predictor variables. Both the Tolerance and VIF tests approach 1 suggesting little multicollinearity. We rely on the work of Knofczynski and Mundfrom (2008) to confirm whether the level of predictive strength given the sample size of 35 is appropriate. With an $\mathrm{R}^{2}$ of 0.549 and three predictor variables in our model, their sample size recommendation for a "good prediction level" (pg. 438, Table 1) lies between 33 and 39.

Table 4. Predictive model (stepwise regression) for GII improvement

\begin{tabular}{cccccc}
\hline Model & $\mathbf{R}$ & $\mathbf{R}^{\mathbf{2}}$ & $\begin{array}{c}\text { Adjusted } \\
\mathbf{R}^{\mathbf{2}}\end{array}$ & $\begin{array}{c}\text { R Square } \\
\text { Change }\end{array}$ & $\begin{array}{c}\text { Durbin- } \\
\text { Watson }\end{array}$ \\
\hline 1 & $.515^{\mathrm{a}}$ & 0.265 & 0.243 & 0.265 & \\
\hline 2 & $.695^{\mathrm{b}}$ & 0.484 & 0.451 & 0.218 & \\
\hline
\end{tabular}




\begin{tabular}{cccccc}
\hline Model & $\mathbf{R}$ & $\mathbf{R}^{\mathbf{2}}$ & $\begin{array}{c}\text { Adjusted } \\
\mathbf{R}^{\mathbf{2}}\end{array}$ & $\begin{array}{c}\text { R Square } \\
\text { Change }\end{array}$ & $\begin{array}{c}\text { Durbin- } \\
\text { Watson }\end{array}$ \\
\hline 3 & $.741^{\mathrm{c}}$ & 0.549 & 0.505 & 0.065 & 1.984 \\
\hline
\end{tabular}

a. Predictors: (Constant), Trade

b. Predictors: (Constant), Trade, Knowledge Diffusion

c. Predictors: (Constant), Trade, Knowledge Diffusion, Intangible Assets

d. Dependent Variable: GII

\section{Excluded Variables}

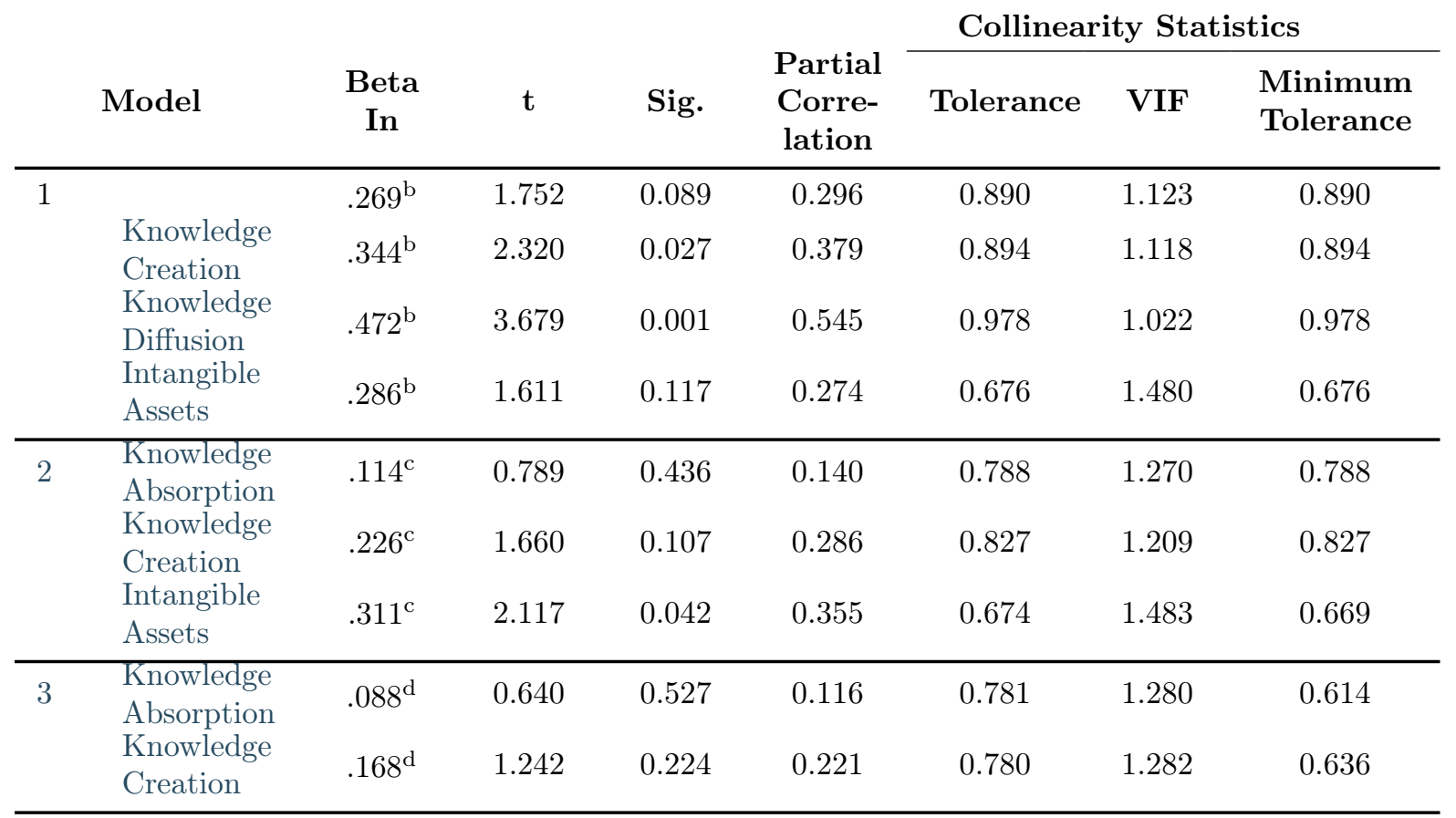
a. Dependent Variable: GII
b. Predictors in the Model: (Constant), Trade
c. Predictors in the Model: (Constant), Trade, KnowDiffusion
d. Predictors in the Model: (Constant), Trade, KnowDiffusion, IntangibleAss

The strongest singular predictive variable; Trade et al., is moderately and positively $(\mathrm{R}=.489 p$ $=.003)$ associated with the Research and Development score. This association was also found by Silaghi et al. (2014) in their economic study of eastern and central European countries where they found that increases in research and development by businesses in those countries were linked to economies that encouraged more trade and competitive (open) markets. Furthermore, scores for both Trade et al. and Research and Development 


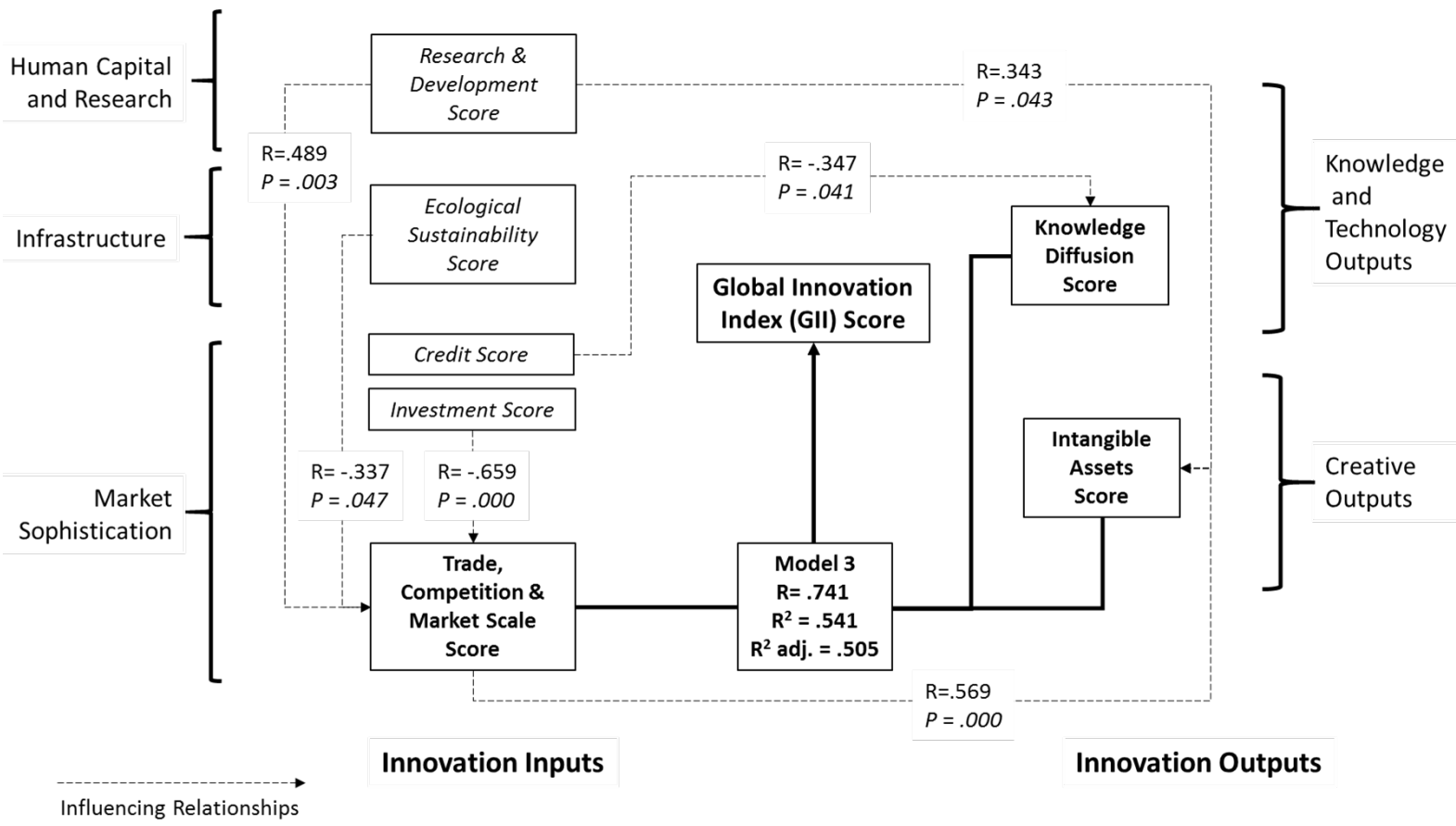

\section{Fig. 2. Innovation drivers influencing predictive Model 3.}

were also found to have moderate positive relationships $(\mathrm{R}=.569 p=.000$ and $\mathrm{R}=.343 p=.043$ respectively)with improvement in the Intangible Assets score, another of Model 3's predictive variables. The association of trademark applications, industrial design applications, and ICT with (Intangible Assets measures) the measures of Research and Development (R\&D expenditures) would seem logical as they are recognized outputs of the R\&D process. More significant is the relatively strong relationship with greater trade, more competitive markets and increased market scale, further confirming the collective role they have in promoting growth in innovation.

There are a three negative associations that have arisen from our analysis and they are worth discussing here. The strongest and most statistically significant is the inverse relationship between the change in a country's Trade et al. score and its Investment score $(\mathrm{R}=-.659 p=.000)$. This result suggests that those countries who increased trade and market competition experienced decreased levels of domestic investment in publicly-traded companies. With increased competition at home, domestic investors might wish to seek opportunities elsewhere to invest their capital especially if external markets are opened as a result of the introduction of open trade policies. We found another more moderate negative correlation $(\mathrm{R}=-.347 p=.041)$ between a country's Credit score and its Knowledge Diffusion score. As countries improved the ability to borrow they saw a decline, in some combination of high-tech and ICT exports, related royalty and licence fees, and net outflows of FDI as a percentage of their gross domestic product (GDP). It is likely the effect is due to the latter, rather than the former, as improving domestic borrowing capacity should encourage domestic lenders to loan capital at home and perhaps limit their investment in external economies, thus reducing the FDI outflows. With the former, increased access to capital should support the ability to fund, and therefore increase, exports. Our final negative association was also a moderate one and was observed between the Trade et al. and Ecological 
Sustainability innovation inputs $(\mathrm{R}=-.337 p=.047)$. From our finding it could be argued that even in developed countries the improving of trade, competition and market scale results in a reduction of some combination of energy efficiency, and environmental performance and compliance. This observation is consistent with the literature in finding that increased open trade and market scale led to greater negative environmental footprints (Al-Mulali and Ozturk, 2015), even specifically within OECD countries (Shafiei and Salim, 2014).

\section{Conclusion and Limitations}

The principal research question driving this study was: What enables improvements in innovation potential among developed countries? Developing economies can no longer rely on labourintensive industries for economic growth and job creation as those industries have moved to developing countries with lower wages and lower costs of operation. In developed countries, policy innovation should remain focused on encouraging inputs and outputs that improve a nation's potential to innovate. This study explored innovation enablers that have a relationship with high innovation performance using an NIS approach. We relied on correlations and regression to identify the specific enablers that contribute to improving a country's innovation potential. By using GII data, we have attempted to understand what NIS' key elements may be more relevant to designing policy for enhancing innovation performance. In this study, we subjected 770 data measures to an analysis of 242 relationships between GII's innovation inputs, outputs and overall innovation potential among 35 OECD countries resulting in the identification of statistically significant relationships between the improvement of certain input/output scores and a nation's total GII score. We used those relationships to produce a predictive regression model that could inform policy on improving a country's innovation capacity. Before stating our conclusions we need to be clear that we are not suggesting that policies to promote innovation within developed countries should exclude any of the many inputs and outputs identified in the GII. Rather, we have attempted to isolate those input/outputs that policy makers may wish to focus on when considering innovation policy.

In terms of our results, we were surprised to find that, with the large number of innovation inputs and outputs contained within the GII framework, there were such few statistically significant relationships found when comparing changes in input/output scores with changes in the total GII score over a recent five year period. However, we find the aggregate predictive model that did emerge is significant in its strength and fit. Therefore we conclude that for the developed nation, the initial focus might be on policies that promote open, competitive markets and the enabling of hi-tech and ICT exports. Furthermore, policy support for continued creative outputs and the development and use of ICT might also be considered. As discussed in our results, there are important relationships with other innovation inputs and outputs that must be considered when structuring policy as suggested. Certainly, the resulting positive association between open, competitive markets that encourage trade, competition and increase in market scale and increased research and development and creative output would be seen by policy makers as beneficial to increased innovation capacity.

However, caution must be taken as some moderate to strong negative associations may exist when 
focusing policy on the results of our predictive model. The most significant may be the potential for decreased investment in domestic capital markets as policies for expanding open-trade and increased competition might encourage domestic investment to seek opportunities externally, especially if reciprocal open market agreements provides access to external markets. The other is the potential environmental impact arising from policies that stimulate economic growth such as easing trade and opening markets. Policy makers may need to consider the importance of balance between innovation and economic need with protection of the environment. Perhaps more importantly, policy that continues to support environmental innovation can be integrated into open market policies in order to mitigate some of the potential harm that may arise.

There are some limitations with our study. We have relied on the integrity of the data presented within the GII report and would recommend that readers review the methodology contained within that report in order to assist in understanding why we have chosen to use this data. Furthermore, we have chosen the scores for each of the inputs and outputs identified by the GII for our statistical measures but we recognize that each input/output is an aggregation of a number of measures that make up the score. Further research might look into specific correlations and regressions within this larger data set. We have also limited ourselves to the most recent five year period and the changes in score of each input/output for the 35 OECD countries to generalize on innovation policy for developed nations. The statistical significance of the correlations and the prediction level of our model may be reasonable but we must rely on the fact that our sample represents almost all of the countries currently defined as developed countries by the United Nations in order for us to make our generalizations.

\section{References}

Al-Mulali, U., \& Ozturk, I. (2015). The effect of energy consumption, urbanization, trade openness, industrial output, and the political stability on the environmental degradation in the MENA (Middle East and North African) region. Energy, 84, 382-389.

Al-Sudairi, M., \& Haj Bakry, S. (2014). Knowledge issues in the global innovation index: Assessment of the state of Saudi Arabia versus countries with distinct development. Innovation, 16(2), 176-183.

Amit, R., \& Schoemaker, P. J. (1993). Strategic assets and organizational rent. Strategic management journal, 14(1), 33-46.

Audretsch, D. B. (1995). Innovation and industry evolution. MIT Press.

Audretsch, D. B., Falck, O., Feldman, M. P., \& Heblich, S. (2012). Local entrepreneurship in context. Regional Studies, 46(3), 379-389.

Audretsch, D. B., Hülsbeck, M., \& Lehmann, E. E. (2012). Regional competitiveness, university spillovers, and entrepreneurial activity. Small Business Economics, 39(3), 587-601.

Audretsch, D., \& Acs, Z. (1990). The entrepreneurial regime, learning, and industry turbulence. Small Business Economics, 2(2), 119-128. doi:10.1007/BF00389672

Balachandra, R., \& Friar, J. H. (1997). Factors for success in R\&D projects and new product 
innovation: a contextual framework. IEEE Transactions on Engineering management, 44(3), 276-287.

Baldwin, J. R., \& Gu, W. (2004). Trade liberalization: Export-market participation, productivity growth, and innovation. Oxford Review of Economic Policy, 20(3), 372-392.

Balzat, M., \& Hanusch, H. (2004). Recent trends in the research on national innovation systems. Journal of Evolutionary Economics, 14(2), 197-210.

Becheikh, N., Landry, R., \& Amara, N. (2006). Lessons from innovation empirical studies in the manufacturing sector: A systematic review of the literature from 1993-2003. Technovation, 26(5), 644-664.

Becheikh, N., Landry, R., \& Amara, N. (2006). Lessons from innovation empirical studies in the manufacturing sector: A systematic review of the literature from 1993-2003. Technovation, 26(5), 644-664.

Bessant, J., Von Stamm, B., Moeslein, K. M., \& Neyer, A. K. (2010). Backing outsiders: selection strategies for discontinuous innovation. REd Management, 40(4), 345-356.

Billon, M., Marco, R., \& Lera-Lopez, F. (2017). Innovation and ICT use by firms and households in the EU: A multivariate analysis of regional disparities. Information Technology 86 People, 30(2), 424-448.

Carayannis, E. G., Grigoroudis, E., Sindakis, S., \& Walter, C. (2014). Business model innovation as antecedent of sustainable enterprise excellence and resilience. Journal of the Knowledge Economy, 5(3), 440-463.

Carayannis, E., \& Grigoroudis, E. (2014). Linking innovation, productivity, and competitiveness: implications for policy and practice. The Journal of Technology Transfer, 39(2), 199-218.

Chandy, R. K., \& Prabhu, J. C. (2011). Innovation typologies. Wiley international encyclopedia of marketing.

Chen, C. J., \& Huang, J. W. (2009). Strategic human resource practices and innovation performance - The mediating role of knowledge management capacity. Journal of Business Research, 62(1), 104-114.

Crespo, N. F., \& Crespo, C. F. (2016). Global innovation index: Moving beyond the absolute value of ranking with a fuzzy-set analysis. Journal of Business Research, 69(11), 5265-5271.

Christensen, A., Møller, A., \& Schwartzbach, M. (2003). Precise analysis of string expressions. Static Analysis, 1076-1076.

Christensen, C. M., \& Bower, J. L. (1996). Customer power, strategic investment, and the failure of leading firms. Strategic management journal, 197-218.

Christensen, Clayton M. (1997). The Innovator's Dilemma: When New Technologies Cause Great Firms to Fail. Boston: Harvard Business School Press.

D'Aveni, R.A., (1994). Hyper competition: Managing the dynamics of strategic maneuvering. Free Press, New York, NY. 
Delgado, M., Ketels, C., Porter, M. E., \& Stern, S. (2012). The determinants of national competitiveness (No. w18249). National Bureau of Economic Research.

Dosi, G. (1988). Sources, procedures, and microeconomic effects of innovation. Journal of economic literature, 1120-1171.

Dubois, P., De Mouzon, O., Scott-Morton, F., \& Seabright, P. (2015). Market size and pharmaceutical innovation. The RAND Journal of Economics, 46(4), 844-871.

Dutta, S., \& Folta, T. B. (2016). A comparison of the effect of angels and venture capitalists on innovation and value creation. Journal of business venturing, 31(1), 39-54.

Edquist, C. (Ed.). (1997). Systems of innovation: technologies, institutions, and organizations. Psychology Press.

Fagerberg, J. (1994). Technology and international differences in growth rates. Journal of Economic Literature, 32(3), 1147-1175. doi:10.2307/2728605

Fagerberg, J., \& Srholec, M. (2008). National innovation systems, capabilities and economic development. Research policy, 37(9), 1417-1435.

Ferreira, S., Cabral, M., da Cruz, N. F., Simões, P., \& Marques, R. C. (2017). The costs and benefits of packaging waste management systems in Europe: the perspective of local authorities. Journal of Environmental Planning and Management, 60(5), 773-791.

Forés, B., \& Camisón, C. (2016). Does incremental and radical innovation performance depend on different types of knowledge accumulation capabilities and organizational size?. Journal of Business Research, 69(2), 831-848.

Freeman, C. (1987). Technical innovation, diffusion, and long cycles of economic development. In The long-wave debate(pp. 295-309). Springer, Berlin, Heidelberg.

Freeman, C. (1995). The 'National System of Innovation' in historical perspective. Cambridge Journal of economics, 19(1), 5-24.127-154). University of Chicago Press.

Freeman, C., \& Soete, L. (1997). The economics of industrial innovation. Psychology Press.

Fritsch, M., \& Meschede, M. (2001). Product innovation, process innovation, and size. Review of Industrial organization, 19(3), 335-350.

Fritsch, M., \& Meschede, M. (2001). Product innovation, process innovation, and size. Review of Industrial organization, 19(3), 335-350.

Furman, J. L., Porter, M. E., \& Stern, S. (2002). The determinants of national innovative capacity. Research policy, 31(6), 899-933.

Garcia, R., \& Calantone, R. (2002). A critical look at technological innovation typology and innovativeness terminology: A literature review. The Journal of Product Innovation Management, 19(2), 110-132. doi:10.1016/S0737-6782(01)00132-1

Global Entrepreneurship Monitoring, (GEM), (2016). Retrieved from http://www.gemconsortium.org Godin, B. (2006). The knowledge-based economy: conceptual framework or buzzword?. The Journal of technology transfer, 31(1), 17-30. 
Godin, B. (2006). The linear model of innovation: The historical construction of an analytical framework. Science, Technology, \&5 Human Values, 31(6), 639-667.

Godin, B. (2007). Science, accounting and statistics: The input-output framework. Research Policy, 36(9), 1388-1403.

Govindarajan, V., \& Kopalle, P. K. (2006). The usefulness of measuring disruptiveness of innovations ex post in making ex ante predictions. Journal of product innovation management, 23(1), $12-18$.

Grossman, G. M., \& Helpman, E. (1991). Quality ladders in the theory of growth. The Review of Economic Studies, 58(1), 43-61.

Grupp, H., \& Schubert, T. (2010). Review and new evidence on composite innovation indicators for evaluating national performance. Research Policy, 39(1), 67-78.

$\mathrm{Gu}$, S. (1999). Implications of National Innovation Systems for Developing Countries: managing change and complexity in economic development (No. 03). United Nations UniversityINTECH.

Haeussler, C., Patzelt, H.,\& Zahra, S. A. (2012). Strategic alliances and product development in high technology new firms: The moderating effect of technological capabilities. Journal of Business Venturing, 27(2), 217-233.

Hasan, I., \& Tucci, C. L. (2010).The innovation-economic growth nexus: Global evidence. Research Policy, 39(10), 1264-1276.

Hurmelinna-Laukkanen, P. (2009), "The availability, strength and efficiency of appropriability mechanisms - protecting investments in knowledge creation", International Journal of Technology Management, Vol. 45 Nos 3/4, pp. 282-90.

Hurmelinna, P., Kyla"heiko, K. \& Jauhiainen, T. (2007), "The Janus face of the appropriability regime in the protection of innovations: theoretical re-appraisal and empirical analysis", Technovation, Vol. 27 No. 3, pp. 133-44.

Jackson, P., Runde, J., Dobson, P., \& Richter, N. (2016). Identifying mechanisms influencing the emergence and success of innovation within national economies: a realist approach. Policy Sciences, 49(3), 233-256.

Khedhaouria, A., \& Thurik, R. (2017). Configurational conditions of national innovation capability: A fuzzy set analysis approach. Technological Forecasting and Social Change, 120, 4858.

Kirchhoff, B. A. (1994). Entrepreneurship and dynamic capitalism: The economics of business firm formation and growth. ABC-CLIO.

Lee, C. (1990). Determinants of national innovativeness and international market segmentation. International Marketing Review, 7(5).

Li, Y., \& Vanhaverbeke, W. (2009). The effects of inter-industry and country difference in supplier relationships on pioneering innovations. Technovation, 29(12), 843-858. doi:10.1016/j.technovation.2009.08

Lim, C. P., Zhao, Y., Tondeur, J., Chai, C. S., \& Chin-Chung, T. (2013). Bridging the gap: 
Technology trends and use of technology in schools. Journal of Educational Technology \& Society, 16(2).

Linton, J. D. (2002). Forecasting the market diffusion of disruptive and discontinuous innovation. IEEE Transactions on engineering management, 49(4), 365-374.

Liu, X., \& Buck, T. (2007). Innovation performance and channels for international technology spillovers: Evidence from Chinese high-tech industries. Research policy, 36(3), 355-366.

Lundvall, B. A. (1992). National innovation system: towards a theory of innovation and interactive learning. Pinter, London.

Lundvall, B. A. (2007). National innovation systems - analytical concept and development tool. Industry and innovation, 14(1), 95-119.

Lundvall, B.-A. (Ed.), 1992. National System of Innovation. Towards a Theory of Innovation and Interactive Learning. Pinter Publishers, London. 1992 Lundvall

MacPherson, A. (1997). The role of producer service outsourcing in the innovation performance of New York State manufacturing firms. Annals of the association of American Geographers, 87(1), $52-71$.

Mansfield, E. (1984). R\&D and innovation: some empirical findings. In RED, patents, and productivity (pp.

McDermott, C. M., \& O'Connor, G. C. (2002). Managing radical innovation: an overview of emergent strategy issues. Journal of product innovation management, 19(6), 424-438.

McDermott, C. M., \& O'Connor, G. C. (2002). Managing radical innovation: an overview of emergent strategy issues. Journal of product innovation management, 19(6), 424-438.

Mercan, B., \& Goktas, D. (2011). Components of innovation ecosystems: a cross-country study. International Research Journal of Finance and Economics, 76(16), 102-112.

Moschini, G., \& Yerokhin, O. (2008). Patents, research exemption, and the incentive for sequential innovation. Journal of Economics \&3 Management Strategy, 17(2), 379-412.

Nasierowski, W. (2009). A conceptual framework for formalization of National Innovation Systems. Foundations of Management, 1(2), 159-166.

Nelson, R. R. (Ed.). (1993). National innovation systems: a comparative analysis. Oxford university press.

OECD (2005). Economics Policy Reforms: going for growth. Paris: OECD

Oglobina, S. Y., Faria, A. P., \& Cabral-Cardoso, C. (2002). Research and development in Russia and its role in national competitiveness. International Journal of Innovation Management, 6(02), 131-161.

Ouellet, P., \& Raoub, L. (2006). Vers une politique de Développement économique Canada en matière de commercialisation des technologies et de l'innovation. Montréal: Développement économique Canada.

Porter, Michael E. (1991). A study prepared for the Business Council on National issues and 
the Government of Canada, "Canada at the Crossroads, the Reality of a new competitive environment." Harvard Business School (October).

Prim, A. L., Filho, L. S., Zamur, G. A. C., \& Di Serio, L. C. (2017). The relationship between national culture dimensions and degree of innovation. International Journal of Innovation Management, 21(01), 1730001.

Ray, S., \& Ray, P. K. (2011). Product innovation for the people's car in an emerging economy. Technovation, 31(5), 216-227.

Raymond, L., \& St-Pierre, J. (2010). R\&D as a determinant of innovation in manufacturing SMEs: An attempt at empirical clarification. Technovation, 30(1), 48-56.

Reinhardt, R., \& Gurtner, S. (2015). Differences between early adopters of disruptive and sustaining innovations. Journal of Business Research, 68(1), 137-145.

Rice, M. P., Leifer, R., \& O'Connor, G. C. (2002). Commercializing discontinuous innovations: bridging the gap from discontinuous innovation project to operations. IEEE Transactions on Engineering Management, 49(4), 330-340.

Roberts, R. (1998). Managing innovation: The pursuit of competitive advantage and the design of innovation intense environments. Research policy, 27(2), 159-175.

Romer, P. M. (1986). Increasing returns and long-run growth. The Journal of Political Economy, 94 (5), 1002-1037. doi:10.2307/1833190

Sainio, L. M., Ritala, P., \& Hurmelinna-Laukkanen, P. (2012). Constituents of radical innovation - exploring the role of strategic orientations and market uncertainty. Technovation, 32(11), 591-599.

Schumpeter, J. A. (1947). The creative response in economic history. The journal of economic history, 7(2), 149-159.

Shane, S., \& Venkataraman, S. (2003). Guest editors' introduction to the special issue on technology entrepreneurship. Research policy, 32(2), 181-184.

Silaghi, M. I. P., Alexa, D., Jude, C., \& Litan, C. (2014). Do business and public sector research and development expenditures contribute to economic growth in Central and Eastern European Countries? A dynamic panel estimation. Economic Modelling, 36, 108-119.

Sonrexa, J., \& Moodie, R. (2013). The race to be the perfect nation. Australian Economic Review, 46(1), 70-77. 10.1111/j.1467-8462.2013.12006.x

Shafiei, S., \& Salim, R. A. (2014). Non-renewable and renewable energy consumption and CO2 emissions in OECD countries: A comparative analysis. Energy Policy, 66, 547-556.

Sohn, S. Y., Kim, D. H., \& Jeon, S. Y. (2016). Re-evaluation of global innovation index based on a structural equation model. Technology Analysis $\& 3$ Strategic Management, 28(4), 492-505.

Stagni, R. M., Fosfuri, A., \& Santalo, J. (2017, January). Unpacking the Impact of Competition on Innovation Strategies: Exploration vs Exploitation. In Academy of Management Proceedings (Vol. 2017, No. 1, p. 10933). Academy of Management. 
Stokey, N. L. (1995). R\&D and economic growth. The Review of Economic Studies, 62(3), 469-489. doi:10.2307/2298038

Teece, D. J., Pisano, G., \& Shuen, A. (1997). Dynamic capabilities and strategic management. Strategic management journal, 509-533.

Tellis, G. J. (2006). Disruptive technology or visionary leadership? Journal of Product Innovation Management, 23(1), 34-38.

Tontini, G., Picolo, J. D., \& Silveira, A. (2014). Which incremental innovations should we offer? Comparing importance-performance analysis with improvement-gaps analysis. Total Quality Management \& Business Excellence, 25(7-8), 705-719.

Vivarelli, M. (2014). Innovation, employment and skills in advanced and developing countries: A survey of economic literature. Journal of Economic Issues, 48(1), 123-154.

Watkins, A., Papaioannou, T., Mugwagwa, J., \& Kale, D. (2015). National innovation systems and the intermediary role of industry associations in building institutional capacities for innovation in developing countries: A critical review of the literature. Research Policy, 44(8), 1407-1418.

Wennekers, S., \& Thurik, R. (1999).Linking entrepreneurship and economic growth. Small Business Economics, 13(1), 27-56. Retrieved from http://resolver. scholarsportal . info/resolve/ 0921898x/v13i0001/27_leaeg

Wojnicka-Sycz, E., \& Sycz, P. (2016). Public innovation policy and other determinants of innovativeness in Poland. The Innovation Journal: The Public Sector innovation Journal, 21(3), Article 2.

Woolley, J. L., \& Rottner, R. M. (2008). Innovation policy and nanotechnology entrepreneurship. Entrepreneurship theory and practice, 32(5), 791-811.

Zanello, G., Fu, X., Mohnen, P., \& Ventresca, M. (2016). The creation and diffusion of innovation in developing countries: a systematic literature review. Journal of Economic Surveys, 30(5), 884912. 


\section{Biographies}

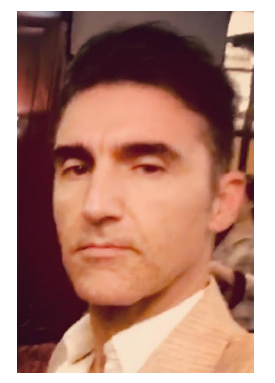

Agostino Menna. Dr. Agostino Menna is the principle co-founder of KnowQuest Inc., an EdTech startup in Toronto, Canada. He has held various academic positions including Ryerson University, Niagara University, and Niagara College of Applied Arts \& Technology. He participated in several incubators including ihub, Spark Niagara, and is most recently involved with ICUBE from the University of Toronto. He is currently an advisor at the Fashion Zone and the Big Leaf Consulting. His research interests are innovation, strategy and agricultural entrepreneurship. He holds a $\mathrm{PhD}$ from the University of Toronto.

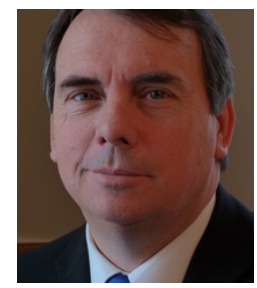

Philip R. Walsh. Dr. Walsh is an Associate Professor, Entrepreneurship \& Strategy at the Ted Rogers School of Management. He was formerly a Lecturer in Corporate Strategy and MBA Programme Director at the University of Surrey, U.K. Prior to joining academia in 2003, he was the Managing Director of a consultancy that provided strategic planning and policy services to major energy utilities, a number of governmental and municipal agencies, and various Canadian and British energy consuming organizations. Dr. Walsh is a Researcher with Ryerson's Center for Urban Energy, a Fellow of the Ryerson Entrepreneurship Research Institute and a member of the Ryerson Institute for the Study of Corporate Social Responsibility. His research areas include innovation, sustainability and energy policy. He is a registered professional geoscientist in Ontario.

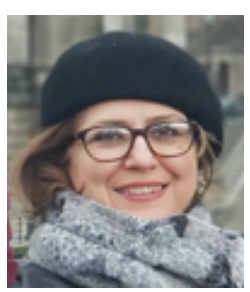

Homeira Ekhtari. Homeira Ekhtari is a Research and Teaching Assistant on Managerial Decision Making, Decision Analysis, and Business Process Design courses at Information Technology Management(ITM), Ted Rogers School of Management, in Toronto, Canada. Also, she is currently pursuing a Ph.D. degree in environmental applied science and management at Ryerson University, Toronto, Canada, which integrates her environmental management experience into the business processes studies. She worked as a Research and Policy Analyst at the Department of Environment(DOE) in Tehran, Iran over ten years before starting her studies in Canada. Her research interests are electronic waste management, decision analysis, information and communication technologies(ICTs), and innovation and business interactions. 